\title{
Critical Study of Dhamaniand Its Division in AyurvedaWsr To Sushruta Samhita
}

\author{
Bhan Pratap Yadaw ${ }^{1 *}$ and Manoj Kumar Gupta ${ }^{2}$ \\ ${ }^{1}$ Department of Rachana Sharir,Govt. Ayurvedic college \& hospital,India \\ ${ }^{2}$ Department ofRoga\&Vikriti Vigyan,Govt. Ayurvedic college \& hospital,India
}

Submission: March 08,2018; Published: August 24, 2018

*Corresponding author: Bhan Pratap Yadaw,Department of Rachana Sharir, Govt. Ayurvedic college \& hospital, Atarra, Banda, India; Pin-210201, Tel: 9451149505; Email: bhanpratapyadaw@gmail.com

Abstract

Cardiovascular System is an important life supporting and nourishing system of the human body. The term hridaya, siras and dhamanis are as old as vedas. They have been generally used in the sense of ayurvedic cardiovascular system.Siras and dhamanis arise from the nabhi (umbilicus) spread throughout the body and supply air to the dhatus constantly.Ayurvedic acharyas has used an anatomical term dhamani, which is one of the controversial terms (structure). The chief difficulty lies in the fact that every writer on the subject approaches the problem with preconceived ideas and tries to read his own views into the ancient texts, which invariably leads to confusion.Dhamanis (arteries) carry rasadhatu all over the body and fill it with air. Dhamanis indicated those ducts which have thick walls and siras those having thin walls.The concept behind origin of siras from nabhi is also supports the origin of dhamanis from nabhi i.e. the time period in which embryo forms in uterus is also the time of formation of dhamani.

Keywords: Ayurveda; dhamani; sushruta; artery; Cardiovascular system; Nourishing system; Human body; Hridaya; Ayurvedic; Anatomy; hridayashrita; Physiology; Lymphatic vessels; Inspiration; Sighing; Yawning; Sneezing; Laughter; Speech; Weeping; Urine; Umbilical veins; Hridaya

\section{Introduction}

Thorough structural scientific knowledge of the life was recommended by ancient acharyas. The knowledge of Rachana Sharira is mandatory for the students of any system of medicine. Acharya Sushruta has said to be the father of surgery because of description available in Sushrutasamhita regarding methodology for learning of the anatomy, dissection on cadaver, dhamani, sira, marma etc. He has given more emphasis on the practical knowledge. A surgeon who desires to obtain thorough knowledge of the body must dissect a dead body properly and see each and every structure and organ in it[1]. In sushrutasamhita, dhamani words are used in many references like- moola of srotasas, nabhinadi, hridayashrita and in various diseases. The standing puzzle of Indian anatomy and physiology is the classification of siras, dhamanis and srotas, the channels, passages and ducts in the body, including the arteries, veins, nerves and lymphatic vessels. The difficulty was felt by the ancient medical writers themselves. All subsequent attempts at clearing up this puzzle have resulted in greater confusion. The functions of the dhamanis also differ.

The up-coursing dhamanisperform such specific functions of the body as sound, touch, taste, sight, smell, inspiration, sighing, yawning, sneezing, laughter, speech, weeping etc. and tend to maintain the integrity of the body. The down-coursing dhamanis form the channels for the downward conveyance of vayu, urine, stool, semen and contaminated fluids'. From the above enumeration of their functions it is seems that dhamanis stand for nerves and ducts. But on critical analysis of cardinal features of dhamani, it should be only artery, not any other anatomical structures. On a critical comparison of the detailed list of siras and dhamanis it will be noticed that no ducts, no specific nerves except the vata vessels, and no rasa carrying vessels are mentioned in the list of the siras. Dhamanis carry rasa all over the body and fill it with air. It is significant that the conveyance of rasa is confined to the dhamanis only[2,3]. Rasa is the end product of digestion of food. It is converted into rakta in the liver and spleen, but its great receptacle is the heart.

The arterial blood of the Indian physiologist is the blood that leaves the liver and the spleen. The distribution of the systematic arteries is like a highly ramified tree, the common trunk of which, formed by the aorta, commences at the left ventricle, while the smallest ramifications extend to the peripheral parts of the body and the contained organs. Arteries are found in all parts of the body, except in the hairs, nails, epidermis, cartilages, and cornea; 
the larger trunks usually occupy the most protected situations, running, in the limbs, along the flexor surface, where they are less exposed to injury. There is considerable variation in the mode of division of the arteries: occasionally a short trunk subdivides into several branches at the same point, as may be observed in the celiac artery and the thyrocervical trunk: the vessel may give off several branches in succession, and still continue as the main trunk, as is seen in the arteries of the limbs; or the division may be dichotomous, as, for instance, when the aorta divides into the two common iliacs[4].

\section{Development and division of Dhamani}

Among the dhamani(arteries) arising from the nabhi (umbilicus), ten spread upward, ten downward and four sideward (transverse). The direction of vessels around the umbilicus has been described by sushrutabut it cannot be precisely said which are these vessels and what can be their actual name, because basically we have not accepted the theory presented by sushrutain relation to the origin of vessels from the umbilicus. Sushruta has used the word "Nabhiprabhava" only because during intra-uterine life the vessels like umbilical arteries and umbilical veins start from the fetal umbilicus. Therefore, one can accept this statement in relation to fetal life. Second view is that the word nabhimight have been used in the sense of heart. Even if it is so then the use of word "nabhi" is also justified. But before one labels "nabhi" fore heart, it should be decided whether scientifically this can be proved or not. Even in charak, astangasangrahaandastangahridaya, nabhi word has been used in reference to fetal life. Sushruta has himself shifted from his own view in relation to the origin of dhamanis from nabhi(umbilicus) to hridaya (heart) in sutrasthan"sonitavarniyaadhyaya" $[5,6]$.

Blood vessels first make their appearance in several scattered vascular areaswhich are developed simultaneously between the endoderm and the mesoderm of the yolk-sac, i. e.,outside the body of the embryo. Here a new type of cell, the angioblastor vasoformativecellis differentiated from the mesoderm ${ }^{7}$.

Charaka has also mentioned in $30^{\text {th }}$ chapter of sutrasthan that the dhamanis (arteries) arise from the hridaya(heart)[8]. Acharya sushruta says that, we will now describe the features of derivations of the foetus, from the father, mother, rasa dhatu (plasma), atma (soul), satva (mind) and satmya (habituation). Kesa(hair of the head), samasru(mustaches) and roma (hairs on the body), asthi (bone), nakha(nails), danta (teeth), sira (veins), snayu(ligaments), dhamanis (arteries) and sukra (semen) etc. which are stable are derived from the pitrija (father). Hridaya (heart) and the pranavahadhamani (arteries sustaining respiration and life) attached to it are produced by the essence of sonita (blood) and kapha[9,10].

Therefore, it can safely be commented that sushruta had a clear idea in his mind that dhamanisare the vessels which originate from nabhi(umbilicus) during fetal life only whereas, they are directly related with the hridaya (heart) after the birth.
As far as the confusion between dhamani, siraand srotas is concerned, he himself has mentioned that this confusion is only because of the close anatomical relationship between dhamani, siraand srotas.

\section{Urdhwagadhamani (dhamani of head and neck region}

Those spreading upward, support (maintain) the body by attending to functions such as receiving sensation of sabda (sound), sparsha (touch), rupa (sight), rasha (taste) and gandha (smell); praswas (inspiration), ucchwas (expiration), jrimbha (yawning), kshavathu (sneezing), hasita (laughing), kathita (talking), ghosita (shouting) and such other functions. These after reaching the hridaya (heart) each one divides into three, thus becoming thirty. Out of these, two each carry vata, pitta, kapha, sonita and rasa - thus ten. two each carry sensation of sabda (sound), rupa (sight), rasha (taste) and gandha (smell); - thus eight. two attends to kathita (speaking in words), two attends to ghosita (shouting or loud sound without words), two attends to swapiti(sleep), and two to pratibudhi (waking), two carry ashru(tears in the eyes), two carry stanya(breast milk) in the breasts of women, these only carry sukra (semen) from the breast in men-thus twelve. Thus, total thirty urdhvagadhamanis are described by their divisions. By these (dhamani), parts of the body above the umbilicus, such as the abdomen, flanks, back, chest, shoulders, neck, arms etc are supported and maintained. The upward dhamani perform all these functions always (throughout life).Dr.ghanekarand gangadher shastri both have submitted his statements in reference to the above couplet[11].

Pandit gangadher shastri has labeled all these dhamani as nerve in the following order. Sabdavahadhamani (auditory nerves), rupavahadhamani (optic nerves), rashavahadhamani (nerves of taste i.e. branch from glassopharyngeal and lingual nerves), gandhvahadhamani (olfactory nerves), bhasandhamani (inferior laryngeal nerves, ghosakardhamani (hypoglossal nerves) and ashruvahadhamani(lacrimal nerves).

Dr. Ghanekar preferred to label some of these vessels as internal auditory artery for sabdavahadhamani (voice carrying vessels), central retinal artery for sense of rupavahadhamani (vision), lingual artery for rashavahadhamani (sense of taste), sphenopalatine branch of internal maxillary artery for gandhvahadhamani (the sense of smell), laryngeal artery for ghosakardhamani (the sense of sound), sublingual artery for bhasandhamani (the sense of speech), lacrimal artery for ashruvahadhamani(the sense of lacrimation), mammary artery for stanyavahadhamani (the sense of lactation)[12]. The modern correlation of urdhwaga dhamani is given below

a. Sabdavahadhamani- Internal auditory artery (acoustic nerve)

b. Rupavahadhamani- Central retinal artery (optic nerve)

c. Rasavahadhamani- Lingual artery (nerves of taste that is branches from glossopharyngeal and lingual) 
d. Gandhavahadhamani-Sphinopalatine branch of the internal maxillary artery (olfactory nerve)

e. Ghosakardhamani- Laryngeal arteries (inferior laryngeal nerve)

f. Bhasandhamani- Sublingual artery (hypoglossal nerve)

g. Ashruvahidhamani- Lacrimal artery (lacrimal nerve)

h. Stanyavahidhamani- Mammary artery

Since the dhamani (arteries) present in the (region of) the heart (the breasts) open after three or four days (after the birth of the child), breast milk gets produced afterwards.

Some urdhwaga dhamanis are related to respiratory movement in which diaphragm and other muscles are involved. So, the blood vessels which supply these muscles are included in these i.e. phrenic and intercostal arteries (phrenic nerve). Except of these local arteries all other functions are controlled by brain. The principal arteries of supply to the head and neck are the two common carotids; they ascend in the neck and each divide into two branches, viz., (1) the external carotid, supplying the exterior of the head, the face, and the greater part of the neck; (2) the internal carotid, supplying to a great extent the parts within the cranial and orbital cavities.So urdhvagadhamanis are correlated with all arteries and its branches which supply to head, neck, brain, upper limbs and thorax[13].

\section{Adhogadhamani (dhamani of abdomen and pelvic region)}

Dhamani (arteries) spreading downward purvey flatus, feaces, semen, and menstrual blood etc downward. These, on reaching the pittasaya acting upon the essence of foods and drinks (known as rasa dhatu) produce by the heat separates it into sara (essence) and kitta (waste). Purveys it throughout the body and nourish the body supplying nutrient materials present in the essence of food, supply it to the dhamani spreading in upward and transverse direction, fill the seat of rasa (hridaya) and separate urine, feces and sweat (from the rasa). In between the amasaya(stomach) and pakvasaya (colon) each one of these (dhamanis) divides into three branches thus becoming thirty; out of these, two each carry vata, pitta, kapha, sonitaand rasathus ten. Two present in the intestine purvey anna, two carry toya (water produce during digestion), two present in the bladder carry urine, two are meant for production of sukra in the testes, and two meant for its elimination, these only purvey the blood known as artava in women and eliminate it; two attached to the large intestine are for expelling the faces- thus twelve. Another eight dhamani supply sweat to those (dhamani) spreading transversely; thus, the thirty branches are described.

By these (dhamani), the parts of the body below the umbilicus such as pakwasaya (large intestines), kati (pelvis), mutrasaya(urinary bladder), purisasaya (organs of feces i.e. rectum), guda (anus), vasti(bladder), medhra (penis) and sakthi (legs) are supported and maintained. Dhamanispreading downward perform these functions all the time (throughout life). Adhogami dhamanis are related to the abdominal region and lower limbs. Vata, mutra, purish, sukraandartava are formed (produced) in abdomen and they move downwards[14].

These substances are formed in their respective organs after getting blood supply from their arteries and then after it move downward direction to pass out from body.Adhogami dhamani moving downward to reach in amasayaand pittasaya. This is the place of pittadhara kala. In this place food are digested and absorbed to form annarasha, which nourishes the body in proper way. These functions (digestion and absorption) of intestine are possible only, when adhogamidhamanis supply blood to intestine. So, this dhamani is called as vivechak (differentiator) and abhivahak (supplier). By the help of adhogamidhamanis, ingested food are digested to form rasa, which moves upward to reach heart through siras (veins) and rasayanis (lymphatic vessels) to nourish the urdhvagaandtiryagadhamanis. It means that nourishment of urdhvagadhamanis is indirectly done by the adhogamidhamanis. After digestion of food material satmyapart of digested food is absorbed by rasa prapa(cisterna chili) and rasa kulya (thoracic duct) to carry it in heart.

Mutra (urine), purisa (fecal matter) and sweda(sweat) are malas ofpakwa anna (digested food). These malas are differentiated in udarvibhag (abdominal region). Swedasravan (sweating) is the function of tiryaggami dhamani, but blood supply to tiryaggami dhamani is the job of adhogamidhamani. Each adhogamidhamanis divided into three branches between the space of amashayaand pakwashaya. The arteries which supplies to amashayaand chhudrantra are capable to move digested food in downward direction i.e. celiac artery and superior mesenteric artery (vagi and sympathetic nerves) are capable to do it.

Mutravahidhamani: The artery which supply blood to the organ where urine is formed. In ayurveda main site of urine is basti (urinary bladder). In this reference we take vessical arteries as mutravahi dhamani. Kavirajgananathsen says that gavini (ureter) is suitable for mutravahidhamani. But, if we understand the urine formation according to modern science then we take renal arteries (nerves from the renal plexus, spermatic, ovarian, inferior mesenteric plexus and hypogastric plexus) as mutravahidhamani.

Sukravahidhamani: Arteries which supply blood to sperm producing organ can be taken as sukravahidhamani i.e. testicular and spermatic arteries (spermatic plexus).

Sukra-visharjinidhamani: In maithun(coitus), sperm produced by testis moves to epididymis, vas deference and prostate. By contraction of urethra sperm ejaculation occurs. In this context arteries supplying to epididymis, vas deference and prostate are considered as sukravisharjinidhamani. 
Varchonirashnidhamani: The function of large intestine is to move fecal matter downward and defecate it outside the body. So, the arteries which help to do this job are called as varcho-nirashnidhamani i.e. inferior mesenteric artery, middle colic and right colic arteries (pelvic visceral nerve).These thirty adhogamidhamani nourishes and support the abdominal organ by supplying blood to it through its branches [15].

The abdominalaortabegins at the aortic hiatus of the diaphragm, in front of the lower border of the body of the last thoracic vertebra, and, descending in front of the vertebral column, ends on the body of the fourth lumbar vertebra, commonly a little to the left of the middle line,by dividing into the two common iliac arteries. The collateral circulation would be carried on by the anastomoses between the internal mammary and the inferior epigastric; by free communication between the superior and inferior mesenterics, if the ligature were placed between these vessels; or by the anastomosis between the inferior mesenteric and the internal pudendal, when (as is more common) the point of ligature is below the origin of the inferior mesenteric; and possibly by the anastomoses of the lumbar arteries with the branches of the hypogastric.The branches of the abdominal aorta may be divided into three sets: visceral, parietal and terminal.

Visceral branches are celiac, superior mesenteric, inferior mesenteric, middle supra-renals,renals,internal spermatics and ovarian (in the female). Parietal branches are inferior phrenics, lumbars and middle sacral arteries. Terminal branches are common iliac arteries. Of the visceral branches, the celiac artery and the superior and inferior mesenteric arteries are unpaired, while the suprarenals, renals, internal spermatics, and ovarian are paired. Of the parietal branches the inferior phrenics and lumbars are paired; the middle sacral is unpaired. The terminal branches are paired16. In modern anatomy adhogamidhamanis are considered as abdominal aorta and its branches. In lower limb there is no any description of special function done by arteries. So, arteries of lower limbs are not described in this context, their names are given as swedamarpayanti[16].

\section{Tiryaggami dhamanis (dhamani of cutaneous region)}

Each one of the four dhamanispreading sideward divide into hundreds and thousands of branches further and so becomes innumerable.By these, the entire body appears to be gavaksita (full of windows); these knit together broadly, their mouths (openings) are attached to the romakupa (hair follicles); these purvey sweda (sweat to the exterior) and rasa (chyme/nutrient tissue) both inside and outside.Through these only the potency (effect) of materials (medicines) used in the form of abhyanga (anointing), parisheka(pouring liquids on the body) and lepa (application of pastes), get cooked (processed by heat) in the skin, enter into the interior of the body.

The sensation of touch both comfortable and uncomfortable, are perceived (understood) by these only[17].
Firstly, it should be decided which arteries are the lateral coursing dhamanis. Lateral coursing can be known as cutaneous arteries which supply the skin, or which go to the sides of body. Upper coursing means those which supply to the head, neck, upper limbs, and thorax. Lower coursing means those which supply to the abdomen and lower limbs. Sushruta could not specifically tell which these four arteries which are directed laterally are. But there is a direct indication of four dhamanis which devides to become thousands, arteries of upper limb and lower limb are not described here. So, we can accept cutaneous vessels of four limbs as four tiryaggami dhamanis[18].Urdhvagami dhamanis are related to head, neck, brain, thorax and upper limbs. Adhogami dhamanis are related to abdominal organs and lower limbs. Tiryaggami dhamanis are related to outer surface of the body i.e. skin. In modern science tiryaggamidhamanis are called as cutaneous or peripheral vessels.

\section{Conclusion}

Apparent similarity between the functions dhamani and nerves is because these functions are interdependent and supplementary to one another. Functions of nerves will not be effective in any part of the body if that part is not supplied with blood by the arteries. Regarding origin and division of dhamani, it can safely be commented that sushruta had a clear idea in his mind that dhamanis are the vessels which originate from nabhi during fetal life only whereas, they are directly related with the hridaya after the birth.As far as twenty-four numbers is concerned, there is presence of cardinal veins, vitelline plexuses, umbilical veins and umbilical arteries seen in this area during the intra uterine life.Therefore, this statement of twenty-four dhamani (vessels) arising out of the nabhi (umbilicus) appear to be hypothetical.

\section{References}

1. Susruta, Sharir Sankhyavyakarana (2010) sharirsthan In: Murthy Shrikant KR, Susruta Samhita (Eds.), Vol. I, English translation Chowkhambha orientalia, Varanasi, $\left(5^{\text {th }}\right.$ edn), Reprint. pp.102.

2. Susruta, Dhamanivyakarna (2010) sharirsthan In: Murthy Shrikant KR, Susruta Samhita (Eds.), Vol. I, English translation Chowkhambha orientalia, Varanasi, Reprint. pp.141-142.

3. Sharangdhar, Sharangdhar Samhita, with commentaries (2009) Deepika In: Bhishagvara Adhamalla and Gudharthadipika kashiram, Chaukhamba surbharti prakashan, Varanasi. Purvakhanda 5/39, pp.24.

4. GRAY'S Anatomy (2008) In: Susan Standring, Section-8, CHURCHIL LIVINGSTONE ELSEVIER, (14 ${ }^{\text {th }}$ edn) pp.1048.

5. Susruta, Dhamanivyakarna (2010) sharirsthan In: Murthy Shrikant KR, Susruta Samhita Vol. I, English translation Chowkhambha orientalia, Varanasi, Reprint ( $9^{\text {th }}$ edn) pp.141.

6. Susruta, sonitavarniya adhyaya (2010) sutrasthan In: Murthy Shrikant KR, Susruta Samhita Vol. I, English translation Chowkhambha orientalia, Varanasi, Reprint (14 $4^{\text {th }}$ edn) p.86.

7. GRAY'S Anatomy (2008) In: Susan Standring, Section-8, CHURCHIL LIVINGSTONE ELSEVIER, (14 th $^{\text {th }}$ edn)p.339.

8. Agnivesha, Arthedasamahamuliya (2009) sutra sthan In: Sharma RK et al. (Eds.), ( $3^{\text {rd }}$ chapter) (with English translation and critical exposition 
based on Chakrapani dutt's Ayurveda dipika) vol I, Chowkhambha Sanskrita Series, Varanasi, (6 $\left.6^{\text {th }} e d n\right)$ p.596.

9. Susruta, Garbhavakranti (2010) sharirsthan In: Murthy Shrikant KR, Susruta Samhita Vol. I, English translation Chowkhambha orientalia, Varanasi, Reprint (edn), p.47-48.

10. Susruta, Garbhavyakarana (2010) sharirsthan In: Murthy Shrikant KR, et al. (Eds.) (4 ${ }^{\text {th }}$ chapter) Vol. I, English translation Chowkhambha orientalia, Varanasi, Reprint (edn)p.60.

11. Susruta, Dhamanivyakarna (2010) sharirsthan In: Murthy Shrikant KR, et al. ( $9^{\text {th }}$ chapter) Vol. I, English translation Chowkhambha orientalia, Varanasi, Reprint (edn) p.142.

12. Susruta, Dhamanivyakarna (2008) sharirsthan In: Ghanekar B G, et al. ( $9^{\text {th }}$ chapter) Vol. I, Meharchand Lakshaman Das Publication, New Delhi, Reprint (edn) pp.233-234.

13. GRAY'S Anatomy (2008) In: Susan Standring, ( $9^{\text {th }}$ chapter) Section-4, CHURCHIL LIVINGSTONE ELSEVIER, (14 $\left.4^{\text {th }} e d n\right)$ pp.397-400.
14. Susruta, Dhamanivyakarna (2010) sharirsthan In: Murthy Shrikant KR, et al. (Eds), (9th chapter) Vol. I, English translation Chowkhambha orientalia, Varanasi, Reprint (edn) pp.142-143.

15. Susruta, Dhamanivyakarna (2008) sharirsthan In: Ghanekar B G, et al. (Eds.), ( $9^{\text {th }}$ chapter) Vol. I, Meharchand Lakshaman Das Publication, New Delhi, Reprint (edn), pp.234-235.

16. GRAY'S Anatomy (2008) In: Susan Standring, Section-8, Churchil Livingstone Elsevier, (14 ${ }^{\text {th }}$ edn) pp.1047.

17. Susruta, Dhamanivyakarna (2010) sharirsthan In: Murthy Shrikant KR, et al. (Eds.), (9 $9^{\text {th }}$ chapter) Vol. I, English translation Chowkhambha orientalia, Varanasi, Reprint (edn) pp.143-145.

18. Susruta, Dhamanivyakarna (2008) sharirsthan In: Ghanekar B G, et al. ( $9^{\text {th }}$ chapter) Vol. I, Meharchand Lakshaman Das Publication, New Delhi, Reprint (edn) pp.235-236.

\section{Your next submission with Juniper Publishers will reach you the below assets}

- Quality Editorial service

- Swift Peer Review

- Reprints availability

- E-prints Service

- Manuscript Podcast for convenient understanding

- Global attainment for your research

- Manuscript accessibility in different formats

( Pdf, E-pub, Full Text, Audio)

- Unceasing customer service

Track the below URL for one-step submission https://juniperpublishers.com/online-submission.php 
